THE JOURNAL OF INFECTIOUS DISEASES - VOL. 146, NO. 4 - OCTOBER 1982

(C) 1982 by The University of Chicago. All rights reserved. 0022-1899/82/4604-0007\$01.02

\title{
Pathogenesis of Foreign Body Infection: Description and Characteristics of an Animal Model
}

\author{
Werner Zimmerli, Francis A. Waldvogel, \\ Pierre Vaudaux, and Urs E. Nydegger
}

\author{
From the Divisions of Infectious Disease and Hematology, \\ Departments of Medicine and Microbiology, \\ University Hospital, Geneva, Switzerland
}

\begin{abstract}
An animal model involving the subcutaneous implantation of tissue cages into guinea pigs and subsequent infection with Staphylococcus aureus was used to study factors pertinent to foreign body infection. Whereas $10^{8}$ colony-forming units (cfu) of $S$. aureus strain Wood 46 did not produce any abscesses in the absence of foreign material, $10^{2}$ cfu was sufficient to infect $95 \%$ of the tissue cages despite the presence of polymorphonuclear leukocytes (PMNLs) in sterile tissue cage fluid. Opsonization of $S$. aureus by tissue cage fluid was adequate during the first hour of infection, but opsonic coating of the organisms decreased at $20 \mathrm{hr}$ after the induction of infection. PMNLs from sterile tissue cage fluid showed decreased phagocytic and bactericidal activities when compared with PMNLs from either blood or peritoneal exudate obtained after short- or long-term stimulation $(P<0.001)$.
\end{abstract}

The enhanced risk of bacterial infections in the vicinity of a foreign body - such as sutures and metallic or polymeric implants-has been repeatedly documented in cardiovascular [1-3], orthopedic [4-6], plastic reconstructive [7], and general [8] surgery. Staphylococcus aureus, Staphylococcus epidermidis, and Escherichia coli are most frequently implicated as the etiologic agents [9]. Foreign body infection proceeds by two possible routes: early infection, due to local bacterial contamination during surgery [4], and late infection, after occasional seeding of microorganisms by the hematogenous route [6]. Both types of infections, once established, rarely heal, and excision of the foreign body remains the only effective treatment.

Received for publication November 9, 1981, and in revised form April 26, 1982.

A preliminary abstract (no. 576) of this work was published in the Program and Abstracts of the 2Ist Interscience Conference on Antimicrobial Agents and Chemotherapy.

This work was supported by grant no. 3.836.0-79 from the Swiss National Research Foundation. Dr. Zimmerli is the recipient of fellowship no. 83.750.0-79 from the Swiss National Research Foundation.

We thank Dr. Kenneth Timmis for suggestions and help in revision of the manuscript; M. Bieri, E. Huggler, and A. Kahr for technical assistance; and F. Michaud for secretarial assistance.

Please address requests for reprints to Dr. Francis A. Waldvogel, Infectious Disease Division, Department of Medicine, University Hospital, 1211 Geneva 4, Switzerland.
The factors responsible for the enhanced risk of bacterial infection of foreign bodies are not well understood. Ineffectiveness of local host defense mechanisms against pyogenic organisms is suggested by the classical experiments of Elek and Conen [10], James and MacLeod [11], and Noble [12], which showed that infection could be produced with as few as $100 \mathrm{cfu}$ of $S$. aureus in the vicinity of silk sutures. Although polymorphonuclear leukocytes (PMNLs) accumulating around a foreign body appear microscopically normal, their functional status as well as the opsonizing capacity of the surrounding fluid have never been explored because of the lack of an appropriate animal model. In the present communication we describe the development of an animal model that reproduces the clinical characteristics of a foreign body infection and thus allows the in vitro evaluation of the various phagocytic steps in its neighborhood [13-16].

\section{Materials and Methods}

Tissue cages, animals, and implantation of tissue cages. Rigid polymethacrylate and polytetrafluoroethylene tubes (internal and external diameters, 10 and $12 \mathrm{~mm}$, respectively; length, 32 $\mathrm{mm}$ ) were perforated by $\sim 250$ regularly spaced holes (diameter, $1 \mathrm{~mm}$ ) and sealed at each end with a cap of identical material.

Tricolor guinea pigs weighing 500-600 g each which were allowed free access to food and which 
were housed individually were used throughout the experiments. After im induction of a neuroleptanalgesia $(0.1 \mathrm{ml} / 100 \mathrm{~g}$ of body weight; Hypnorm $^{\circledR}$; Duphar, Amsterdam), a 4-cm incision was made with an aseptic technique, and the sc space was dissected bluntly. One gas-sterilized tissue cage was implanted in each flank [17-20], and the skin was closed with metal clips, which were removed five days after surgery. The animals were used for experimentation two or more weeks after implantation of the tissue cages, after full healing of the incision.

Cytologic, microbiologic, and protein determinations. Erythrocytes and leukocytes from freshly obtained tissue cage fluids were counted in a hemacytometer with trypan blue and Turk's stain, respectively. Cell viability was evaluated by exclusion of trypan blue. Quantitative bacterial cultures were performed on Mueller-Hinton agar, after lysis of PMNLs and appropriate serial dilutions in sterile water. Possible clumping of bacteria was checked for regularly and found to be minimal under these experimental conditions. The absence of spontaneous bacterial contamination of tissue cage fluids was confirmed by subculturing undiluted tissue cage fluid on blood agar and incubating the plates for $48 \mathrm{hr}$. Protein was quantitated by the Bio-Rad ${ }^{\circledR}$ protein assay (Bio-Rad Laboratories, Richmond, Calif.).

Collection and storage of serum and tissue cage fluid. Blood was obtained by cardiac puncture and allowed to clot at $37 \mathrm{C}$ for $30 \mathrm{~min}$. Serum was separated thereafter by centrifugation at $1,500 \mathrm{~g}$ for $10 \mathrm{~min}$ at $4 \mathrm{C}$, stored at $-70 \mathrm{C}$, and tested within three months. Tissue cage fluid was collected by percutaneous aspiration, added to icecold siliconized glass tubes, centrifuged, and stored under the same conditions as serum. Pools of either serum or tissue cage fluid were obtained by mixing such samples from at least five healthy guinea pigs.

Experimental infections. S. aureus strain Wood 46 , stored in aliquots of the same initial culture at $-70 \mathrm{C}$, was used for all experiments. Overnight cultures in Mueller-Hinton broth were washed and resuspended in $0.9 \% \mathrm{NaCl} ; 0.1 \mathrm{ml}$ of an appropriate dilution was injected into tissue cages, sc tissue, or the peritoneal cavity. The number of viable bacteria injected was checked by plating 0.1 $\mathrm{ml}$ of a $10^{-6}$ dilution of the washed overnight culture, which contained $7-15 \times 10^{8} \mathrm{cfu} / \mathrm{ml}$.
In addition, the following infections were attempted under identical experimental conditions: (I) inoculation of sc cavities created by surgical extraction of tissue cages implanted four weeks previously; (2) inoculation of sc, longitudinallyhalved tissue cages, thus allowing granulation tissue to grow on either side of the cage wall; or (3) before inoculation $S$. aureus strain Wood 46 was preopsonized by incubation with $10 \%$ serum for $30 \mathrm{~min}$ at $37 \mathrm{C}$, followed by two washes with $0.9 \%$ $\mathrm{NaCl}$. The efficacy of the preopsonization procedure was assessed in an in vitro phagocytic assay without further addition of opsonins (serum or tissue cage fluid).

Preparation of leukocytes. Acute peritoneal exudates rich in PMNLs $(>95 \%)$ were obtained from guinea pigs by ip injections of either $12 \%$ (wt/vol) sterile caseinate in $0.9 \% \mathrm{NaCl}$ [21] or $0.1 \%$ (wt/vol) sterile glycogen in $0.9 \% \mathrm{NaCl}$ [22]. Persistent peritonitis as a paradigm for a chronic exudate in the absence of a foreign body was produced by repeated injections of glycogen over a period of two weeks. After such a sustained stimulus, these exudates showed the same leukocyte differential count as tissue cage fluid $-40 \%$ PMNLs and $60 \%$ mononuclear leukocytes; histopathologic examination of sections confirmed the presence of a chronic inflammation. The exudates were collected by abdominal lavage with an 18-gauge needle and were filtered through four layers of gauze (pore size, $1 \times 2 \mathrm{~mm}$ ) into ice-cold siliconized glass tubes. The cell suspensions were washed three times in cold $0.9 \% \mathrm{NaCl}$ by centrifugation at $150 \mathrm{~g}$ for $10 \mathrm{~min}$ and resuspended in $5 \mathrm{ml}$ of a solution of phosphate-buffered saline (Dulbecco's Gibco-Bio-Cult Co., Glasgow, Scotland). The total yield of PMNLs harvested by these techniques usually exceeded $10^{8}$ cells $(>95 \%$ PMNLs) per animal with acute peritonitis and $6 \times$ $10^{7}$ cells ( $\sim 40 \%$ PMNLs) per animal with persistent peritonitis. PMNLs from blood were obtained as a $60 \%-80 \%$ pure suspension by the method described by Chenoweth et al. [23]. PMNLs from sterile tissue cage fluid were aspirated percutaneously from tissue cages (two to five weeks after surgery) and washed as described above. When necessary, PMNLs were concentrated by centrifugation or by pooling cells from two tissue cages from the same animal. PMNLs from infected tissue cages were aspirated with the same technique, washed, and resuspended in 
phosphate-buffered saline. This procedure as well as the dilution of the cell suspension to an appropriate concentration of PMNLs for the phagocytic assay decreased the number of bacteria present in infected tissue cage fluid from $10^{6}$ to $10^{4}$ $\mathrm{cfu} / \mathrm{ml}$ - that is, to $0.3 \%$ of the number of indicator bacteria used in the assay.

Phagocytic bactericidal assay. The same phagocytic bactericidal assay previously described by our laboratory $[13,24]$, was used throughout the present study to measure opsonic activities of tissue cage fluid and serum, the opsonic coating of $S$. aureus in the animal model, and the overall killing by as well as the ingestion rate of PMNLs.

Opsonic activity. An overnight culture of $S$. aureus strain Wood 46 was washed three times in distilled water by centrifugation at $3,000 \mathrm{~g}$ for $10 \mathrm{~min}$ and finally resuspended in $1 \mathrm{ml}$ of $0.9 \%$ $\mathrm{NaCl}$. Under such conditions, most bacteria appeared as single cocci on Gram stain, thus minimizing errors in cfu enumeration due to clumping, as we have shown previously [13, 24, 25]. Guinea pig PMNLs, bacteria, and the opsonic source to be tested were suspended in phosphatebuffered saline in siliconized glass tubes in a final volume of $1 \mathrm{ml}$. Each $1 \mathrm{ml}$ of incubation mixture contained $5 \times 10^{6}$ PMNLs, $1.5-3 \times 10^{6} \mathrm{cfu}$ of $S$. aureus, and $0.1 \mathrm{ml}$ of a serially diluted source of opsonins. The incubation and plating conditions have been described $[13,24,25]$. The reciprocal value of the dilution of serum or tissue cage fluid that gave $50 \%$ killing of $S$. aureus was defined as the opsonic titer [13, 24]. Controls included (1) heat-inactivated (at $56 \mathrm{C}$ for $30 \mathrm{~min}$ ) pooled serum or tissue cage fluid with PMNLs; (2) PMNLs without serum or tissue cage fluid; and (3) $10 \%$ pooled serum without PMNLs. None of these controls exhibited any bactericidal activity against the test strain. The lack of bacterial killing with heatinactivated serum as the opsonic source confirmed the previously defined opsonic requirements of $S$. aureus strain Wood 46 [13, 24, 26].

Opsonic coating of bacteria. Experimentally infected tissue cage fluids were aspirated 1 and 20 hr after inoculation of bacteria, and the opsonic coating of the bacteria was assessed as follows. The microorganisms were washed three times in $0.9 \% \mathrm{NaCl}$ and resuspended in phosphate-buffered saline. For each assay $0.5 \mathrm{ml}$ of this bacterial suspension was added to a suspension of $0.5 \mathrm{ml}$ of peritoneal PMNLs $\left(5 \times 10^{6}\right)$ in phosphate-buf- fered saline and incubated without addition of any other opsonic source at $37 \mathrm{C}$ in a shaking water bath. Samples of the test suspension were taken at zero-time and after $30 \mathrm{~min}$ of incubation, and bacterial survival was determined as described above. Simultaneous controls were obtained by preopsonizing an aliquot of the same bacterial suspension with either $10 \%$ heat-inactivated (at $56 \mathrm{C}$ for $30 \mathrm{~min}$ ) or $10 \%$ freshly obtained serum. Preopsonization of the bacteria with heat-inactivated serum did not increase the bacterial killing measured in the phagocytic bactericidal assay.

Phagocytic bactericidal capacity of PMNLs. The testing of the phagocytic bactericidal potential of PMNLs obtained from tissue cage fluids or peritoneal exudates presupposed that the opsonic source used in the phagocytic assay was not ratelimiting. This requirement was met by using $\geqslant 2.5 \%$ pooled serum or $\geqslant 10 \%$ sterile tissue cage fluid as the opsonic source [27].

Because PMNLs in tissue cages were unable to eliminate inocula as small as $10^{2} \mathrm{cfu}$ of $S$. aureus (see below), we assessed the in vitro bactericidal performance of $2 \times 10^{6} \mathrm{PMNLs} / \mathrm{ml}$ not only with the conventional inoculum $\left(4 \times 10^{6} \mathrm{cfu}\right)$, but also with a smaller inoculum of $8 \times 10^{3} \mathrm{cfu}$. After incubation of this suspension with $0.2 \mathrm{ml}$ of pooled, sterile tissue cage fluid at $37 \mathrm{C}$ in a shaking water bath, samples were drawn at zero-time and 30 , 120 , and $240 \mathrm{~min}$, diluted, mixed with an equal volume of $0.2 \%$ Triton X-100 [25], and plated on Mueller-Hinton agar. Each test was accompanied by the following controls: (I) $20 \%$ heat-inactivated tissue cage fluid, which did not promote any bacterial killing, and peritoneal PMNLs, and (2) $20 \%$ freshly obtained tissue cage fluid without PMNLs, which led to bacterial growth after 2 and $4 \mathrm{hr}$ of incubation in all tubes. In this modified assay, control PMNLs exhibited killing capacity which was within the ranges of the standard assay. Control experiments with either $10 \%$ serum or $40 \%$ tissue cage fluid as an opsonic source were also performed and showed identical killing rates in the presence of PMNLs. Moreover, preincubation of $40 \%$ tissue cage fluid with PMNLs from blood, tissue cages, or exudates did not inhibit the cells' phagocytic bactericidal function. Finally, because for technical reasons PMNLs from tissue cages could not be separated from other leukocytes from tissue cages before the in vitro assays, an inhibitory effect of the latter cells on 
PMNL function was excluded by appropriate mixing experiments with tissue cage cells and control PMNLs from peripheral blood.

Ingestion rate of PMNLS. Ingestion rates of PMNLs were tested in a similar phagocytic assay with use of lysostaphin $[25,28,29]$. In brief, this assay consisted of incubating $5 \times 10^{6}$ PMNLs with $1 \times 10^{7}$ cfu of $S$. aureus strain Wood 46 and determining the overall killing in an aliquot after $30 \mathrm{~min}$ of incubation. Intracellular survival was assessed by incubation for another $30 \mathrm{~min}$ in the presence of 20 units of lysostaphin (Sigma Chemical Co., St. Louis), followed by treatment with $0.25 \%$ trypsin (Serva-Feinbiochemica, Heidelberg, Federal Republic of Germany) and neutralization of the proteolytic activity with $10 \%$ serum.

Complement studies. Total hemolytic complement activity was measured in a manual assay [30] and expressed as the reciprocal dilution that gave $50 \%$ hemolysis of sensitized red blood cells $\left(\mathrm{CH}_{50}\right)$. C3 levels were quantitated by single radial immunodiffusion with goat monospecific antibody to guinea pig C3 (Cappel Laboratories, Cochranville, $\mathrm{Pa}$.) [31]. Values were expressed as percentages of the level in pooled normal guinea pig serum.

Statistical analysis. The significance of differences between mean values was determined by Student's $t$-test; the method of paired comparisons was used when appropriate (that is, comparison of opsonic coating at different conditions). For correlation analysis, the Spearman's correlation coefficient was used. Results were expressed as means \pm SEM.

\section{Results}

Composition of normal, sterile tissue cage fluid and histopathology of the inflammatory reaction. After implantation of tissue cages, aspirated fluid showed the following characteristics. Erythrocyte counts decreased from $1.5 \times 10^{8} / \mathrm{ml}$ (range, $\left.0.3-3.6 \times 10^{8}\right)$ at two weeks after surgery to $1 \times$ $10^{7} / \mathrm{ml}$ (range, $0.6-9 \times 10^{7}$ ) at 12 weeks after surgery. Leukocyte counts decreased from $2.4 \times$ $10^{6} / \mathrm{ml}$ (range, $0.3-8.4 \times 10^{6}$ ) at two weeks after surgery to $1 \times 10^{5} / \mathrm{ml}$ (range, $0.5-8 \times 10^{5}$ ) at 12 weeks after surgery. Differential cell counts performed two weeks after implantation of tissue cages showed a slight predominance of PMNLs (60\% PMNLs and 40\% mononuclear leukocytes), as opposed to two months later (30\% PMNLs and $70 \%$ mononuclear leukocytes).

Histologic sections examined four weeks after implantation of tissue cages and stained with hematoxylin and eosin showed a richly vascularized granulation tissue containing lymphocytes, fibroblasts, and collagen fibers in close contact with the foreign body. There was heavy PMNL infiltration in the vicinities of infected tissue cages. Biochemical determinations of levels of calcium, magnesium, phosphorus, and zinc, $\mathrm{pH}, \mathrm{pO}_{2}$, and $\mathrm{pCO}_{2}$ confirmed the results obtained in other animal species $[19,32]$. The protein concentration in tissue cage fluid decreased from $33.0 \pm 1.4$ $\mathrm{g} /$ liter at two weeks to $22.8 \pm 1.1 \mathrm{~g} /$ liter at 11 weeks. These values were significantly lower in tissue cage fluid than in serum $(52.3 \pm 0.9 \mathrm{~g} / \mathrm{liter})$ at any postoperative interval tested $(P<0.001)$.

Induction of infection in tissue cages and determination of the minimal infecting dose. To determine whether implantation of tissue cages is a representative model of foreign body infection, it had to be shown that the minimal infecting dose was close to the values observed in other systems [10-12]. For this purpose, the minimal infecting dose-defined as the number of cfu of $S$. aureus strain Wood 46 leading to a $95 \%$ infection rate-was determined for tissue cage fluid, as well as for sc tissue in the absence of a foreign body. Washed bacterial cultures were injected into tissue cage fluids or sc between weeks 2 and 13 after surgery. Inocula as small as $10^{2} \mathrm{cfu}$ (range, 46-210 cfu) produced infections in $44(95.6 \%)$ of 46 of the tissue cages at $24 \mathrm{hr}$, as determined macroscopical$\mathrm{ly}$ and by bacterial cultures, and inoculation of $\geqslant 10^{3}$ cfu of $S$. aureus resulted in an infection in 40 of 40 tissue cages. The minimal infecting dose was identical whether polymethacrylate or polytetrafluoroethylene tissue cages were used. Autopsies of six animals showed the infection to be confined to the space within and around the tissue cage, without any evidence of spread to other organs; blood cultures were negative. In contrast, no infection could be produced in 30 animals by sc injection of $10^{2}-10^{8}$ cfu of $S$. aureus strain Wood 46 in the absence of tissue cages. Ten animals were used as microbiologic controls for the sterility of sc tissue. For this purpose, the area of diffusion of the inoculated bacteria was determined in preliminary experiments with Evan's blue (Hoffmann-La Roche, Basel, Switzerland). After injection of the 
various bacterial inocula, the area corresponding to the previously determined diffusion zone was biopsied, homogenized, and checked for bacterial growth. All the biopsy specimens were sterile at 72 $\mathrm{hr}$ after injection of inocula as large as $10^{8} \mathrm{cfu}$.

Evaluation of the role of tissue cage dead space. Because the dead space present within tissue cages could create unfavorable conditions for surface phagocytosis, the following control experiments were carried out. Tissue cages were halved longitudinally and implanted as described. Histologic examination confirmed that granulation tissue had gained access to either side of the foreign body. Five of five of these modified tissue cages could still be infected with $<10^{3}$ organisms. The negligible role of the dead space in promoting infection was further demonstrated by removing implanted, sterile tissue cages after four weeks and inoculating the healed sc pouches after removal of the clips with $S$. aureus strain Wood 46 suspended in $4 \mathrm{ml}$ of $0.9 \% \mathrm{NaCl}$. In seven animals no infection could be produced with $10^{9} \mathrm{cfu}$, and in six animals the peritoneal cavity (a natural dead space) could not be infected with $10^{9} \mathrm{cfu}$.

Bacterial growth and leukocyte accumulation during experimental infections of tissue cages. To assess the development of infection in the experimental model, quantitative cultures of $S$. aureus strain Wood 46 were performed in tissue cages over seven days with various initial inocula. At 22 hr after inoculation of from $10^{2}$ to $10^{\mathrm{s}} \mathrm{cfu}$, bacteria reached concentrations ranging from 1.3 $\times 10^{5} \mathrm{cfu} / \mathrm{ml}$ to $5.2 \times 10^{7} \mathrm{cfu} / \mathrm{ml}$, respectively. Further observations over two to seven days showed that bacterial counts fluctuated between $10^{5} \mathrm{cfu} / \mathrm{ml}$ and $10^{8} \mathrm{cfu} / \mathrm{ml}$, regardless of the initial inoculum. These values were lower than those obtained under in vitro conditions in Mueller-Hinton broth $\left(7-15 \times 10^{8} \mathrm{cfu} / \mathrm{ml}\right.$ after $\left.24 \mathrm{hr}\right)$.

Quantitation of viable (trypan blue-negative) leukocytes in tissue cage fluid at induction and during establishment of infection with various inocula is shown in figure 1 . The observed increase in leukocyte counts depended markedly on the inoculum size and on the time elapsed after inoculation, with a lag phase of $2-8 \mathrm{hr}$. At $22 \mathrm{hr}$, leukocyte counts had increased by factors of 5.1- and 40.4-fold from initial inocula of $10^{2}$ and $10^{8}$ bacteria, respectively.

Phagocytic bactericidal activity of PMNLS from tissue cage fluid in the absence or presence of

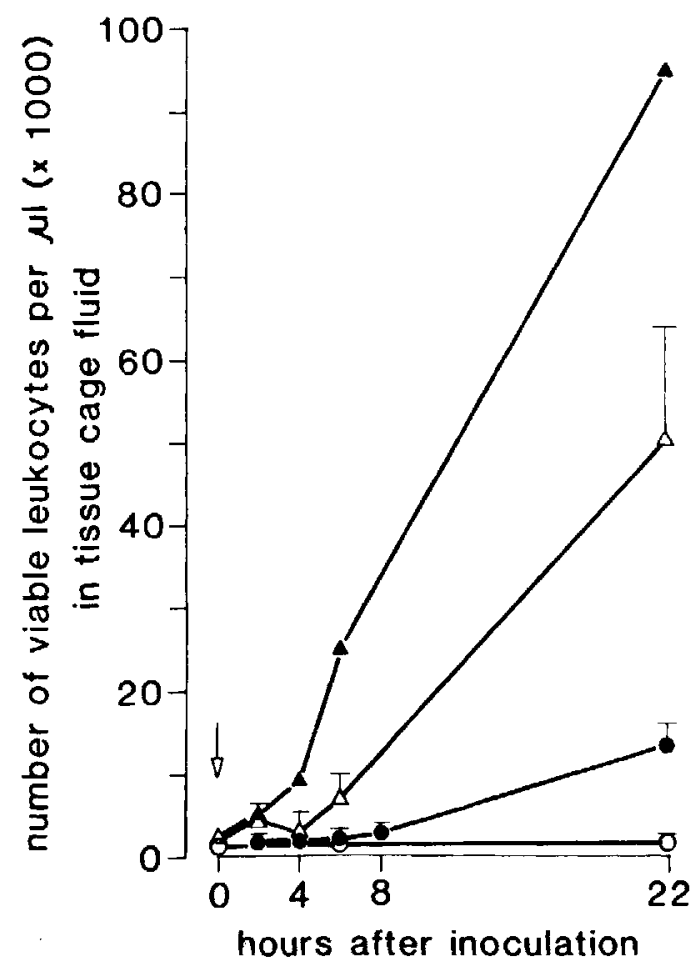

Figure 1. Viable leukocyte counts in tissue cage fluid during experimental infection of guinea pigs with Staphylococcus aureus strain Wood 46. At zero-time (arrow), the indicated inocula were given: (O) $10^{2}$ cfu (seven animals), (๑) $10^{4} \mathrm{cfu}$ (four animals), $(\Delta) 10^{6} \mathrm{cfu}$ (four animals), and $(\boldsymbol{\Delta}) 10^{8} \mathrm{cfu}$ (two animals). Data are mean + SEM (bars) numbers of leukocytes $\times 1,000 / \mu \mathrm{l}$ at intervals after infection.

infection. Bactericidal activity of PMNLs. Because tissue cages could be infected with as few as $10^{2} \mathrm{cfu}$ of $S$. aureus despite the presence of $1 \times$ $10^{4}-5 \times 10^{6} \mathrm{PMNLs} / \mathrm{ml}$, we concluded that the presence of a tissue cage promoted infection even when the bacteria: PMNL ratio varied from $1: 100$ to $1: 50,000$. We therefore examined PMNLs from sterile tissue cages as to their bactericidal function over various incubation times with various bacterial inocula and compared the data with the bactericidal activity of PMNLs from either peripheral blood or peritoneal exudates - that is, unstimulated or attracted PMNLs. Finally, to compare exudates of similar age, the function of PMNLs from tissue cages was compared for each experimental condition with that of peritoneal PMNLs obtained after two weeks of stimulation.

The bactericidal activity of tissue case-derived 


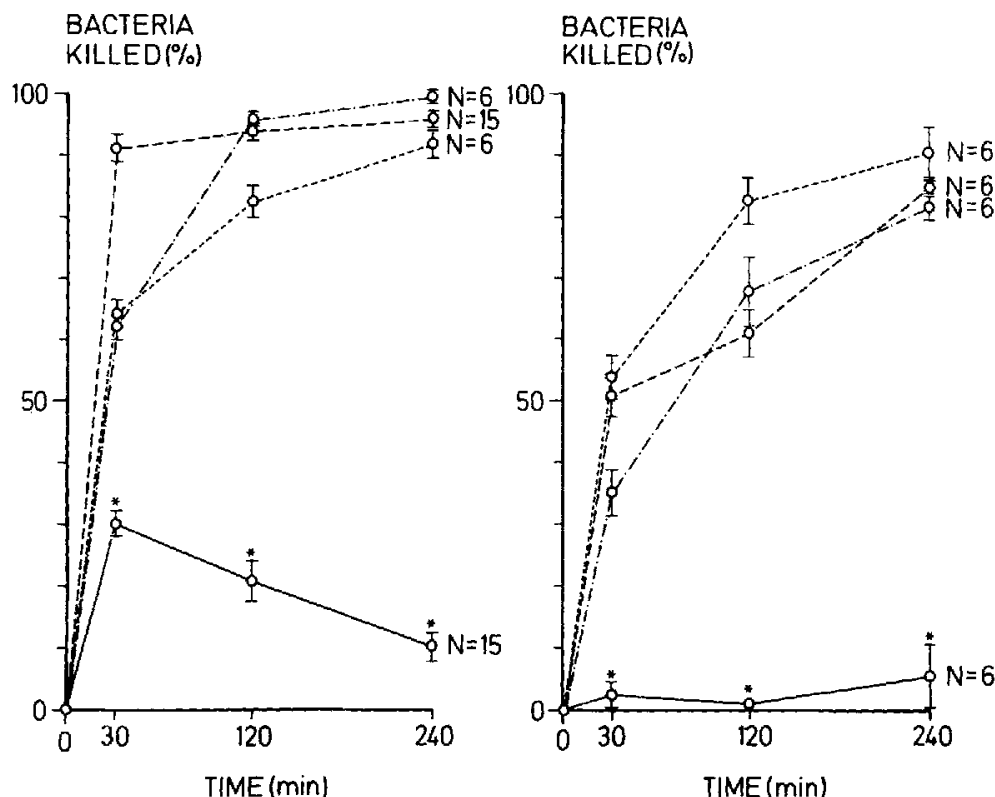

Figure 2. Bactericidal capacity of pol morphonuclear leukocytes (PMNL. from sterile tissue cage fluid at 1 days after implantation in guinea piz $(0-0)$ compared with that $c$ peritoneal exudate PMNLs after sterile acute $(0--O)$ or protracte soluble $\left(\mathrm{O}^{-} \cdot \mathrm{-O}\right)$ stimulation $\mathrm{C}$ PMNLs from peripheral blood ( $0--0$, The phagocytic bactericidal assa contained, in a final volume of $1 \mathrm{~m}$ of phosphate-buffered saline, $0.2 \mathrm{~m}$ of pooled tissue cage fluid, $2 \times 10$ PMNLs, and (left) $8 \times 10^{3} \mathrm{cfu}(\mathrm{bac}$ teria: PMNL ratio, $1: 250$ ) or (right $4 \times 10^{6} \mathrm{cfu}$ (bacteria: PMNL ratio. $2: 1)$ of washed Staphylococcus aureus. Data are means \pm SEM (bars). Asterisks indicate significant difference $(P<0.001)$ in comparison with each of the control PMNL preparations.
PMNLs was considerably lower than activities observed with PMNLs from acute and chronic peritoneal exudates and from peripheral blood (figure 2). This difference was significant with each bacterial inoculum and at each incubation interval tested, a result suggesting that the residential PMNLs in tissue cages were unable to cope with $S$. aureus strain Wood 46, even at minimal inocula. The viabilities of PMNLs from tissue cages, blood, and peritoneal exudate before and after incubation were comparable. Differential counts of leukocytes from tissue cages showed 40\%-70\% PMNLs and 30\%-60\% mononuclear leukocytes; these numbers were comparable to those obtained from persistent peritoneal exudates. In contrast to these results, in 10 assays the overall bactericidal activity of PMNLs accumulating in experimentally infected tissue cages at $20 \mathrm{hr}$ after inoculation was $91.3 \% \pm 1.9 \%$ when tested by standard bactericidal procedure. Similar results were recorded with control PMNLs from peritoneal exudates produced with glycogen or caseinate (bactericidal activity, $86.1 \% \pm 2.4 \%$ [16 animals] and $79.6 \% \pm 3.9 \%$ [10 animals], respectively).

Ingestion rates of PMNLs from sterile tissue cages. To define further the overall bactericidal defect observed with PMNLs from sterile tissue cage fluid, we measured their ingestion rate as well as their intracellular killing rate. In five animals,
PMNLs from tissue cages ingested $49.6 \% \pm 2.3 \%$ and killed $39.1 \% \pm 1.6 \%$ of the $S$. aureus, whereas peritoneal PMNLs ingested 87.2\% \pm $2.2 \%$ and killed $83.1 \% \pm 2.5 \%$ of the bacteria. After determination of the number of ingested bacteria, it could be calculated that $21.1 \% \pm$ $0.5 \%$ of the ingested organisms remained viable in PMNLs from tissue cages, whereas only $4.7 \% \pm$ $0.5 \%$ of the bacteria ingested by control PMNLs survived intracellularly after 30 min of incubation.

Opsonic activity and complement levels of tissue cage fluid in the absence or presence of infection. After having identified a phagocytic and bactericidal defect in PMNLs from tissue cages, we analyzed another component of the phagocytic system-opsonization of the infecting organism. Figure 3 shows complement-mediated opsonic activity and total hemolytic complement levels in sterile tissue cage fluids, expressed as $50 \%$ killing and $\mathrm{CH}_{50}$ units, measured at various intervals after surgery. Both values in tissue cage fluid decreased progressively with time, the opsonic activity being $14.4 \%$ and the complement level being $14.8 \%$ of the serum values at 75 days after surgery. When expressed per gram of protein, the values of the tissue cage fluids corresponded to $33.1 \%$ and $34.0 \%$ of the serum values, respectively. The correlation in 30 animals between the total hemolytic complement level and the opsonic titer was highly 
Figure 3. Opsonic activity and total hemolytic complement level in tissue cage fluid from guinea pigs at intervals after implantation and in pooled normal guinea pig serum. Data are means \pm SEM (bars) of the reciprocal dilutions that gave either $50 \%$ killing of bacteria in a phagocytic assay (K50) or 50\% hemolysis in a hemolytic system $(\mathrm{CH} 50)$. One asterisk indicates $P<0.01$, and two asterisks indicate $P<0.001$ in comparison with values in tissue cage fluid at 15 days after surgery.

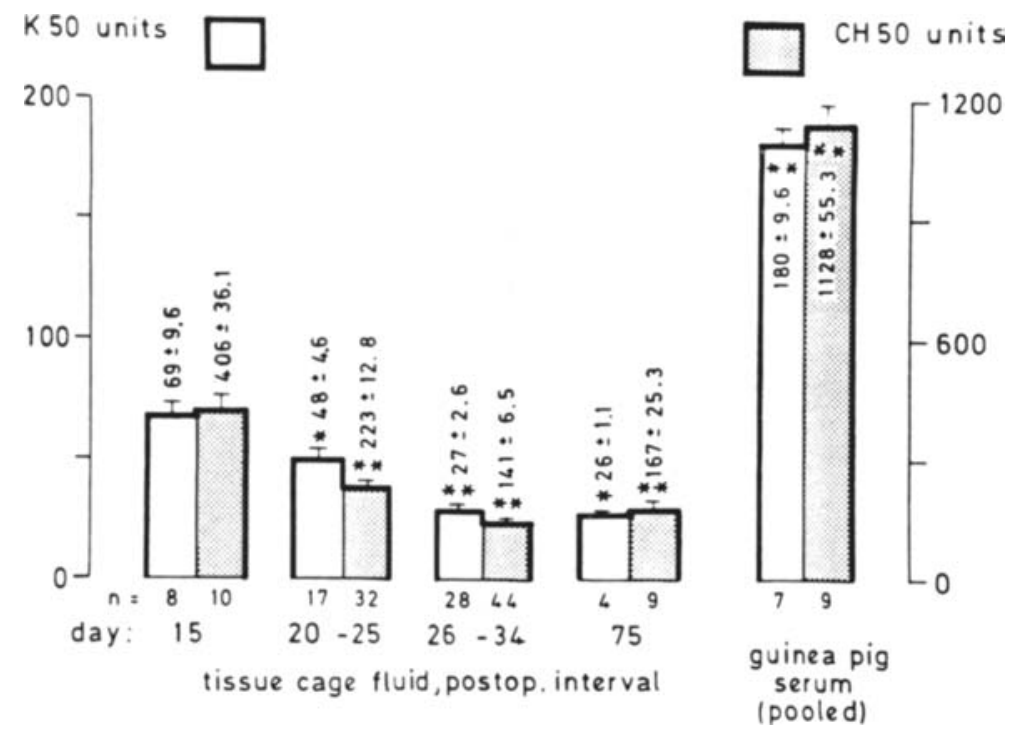

significant $(r=0.81 ; P<0.001)$. In 43 animals, the mean \pm SEM C3 level in tissue cage fluid was $18.6 \% \pm 0.4 \%$ of the serum level.

In view of these low levels of $50 \%$ killing, $\mathrm{CH}_{50}$, and $\mathrm{C} 3$ in tissue cage fluid, we considered the possibility that this fluid might be unable to promote adequate opsonization, as has been described for empyema [13]. To test this hypothesis, $S$. aureus strain Wood 46 was preopsonized in vitro with pooled guinea pig serum before inoculation into tissue cages. Preopsonization of bacteria was confirmed by incubating an aliquot with peritoneal exudate PMNLs for $30 \mathrm{~min}$ in a phagocytic assay which led to a killing rate of $80 \%$. Despite optimal preopsonization, aliquots corresponding to $1.2 \times 10^{2} \mathrm{cfu}$ injected into sterile tissue cages led to infection in four of four animals. Although the kinetics of bacterial growth and death were not formally tested in these experiments, low opsonic activity in tissue cage fluid could not be considered as a rate-limiting factor favoring the development of infection. During the development of infection, opsonic activity and the complement level were measured at 1 and $20 \mathrm{hr}$ after inoculation of $10^{7} \mathrm{cfu}$. The value of $\mathrm{CH}_{50}$ in six animals decreased moderately, from $267 \pm$ 35.2 units to $172 \pm 41.3$ units $(P<0.025)$. Opsonic activity bound to $S$. aureus, however, showed a striking change during the course of the infection. In 20 animals, the opsonic coating of bacteria (figure 4 , left) promoted $75.3 \% \pm 2.9 \%$ killing at $1 \mathrm{hr}$ after infection, whereas killing was decreased to $46.7 \% \pm 7.4 \%$ at $20 \mathrm{hr}(P<0.001)$. The opsonic coating of $S$, aureus could be improved (figure 4 , middle) at $20 \mathrm{hr}$ after infection by injection of $0.5 \mathrm{ml}$ of fresh autologous serum (final concentration, 25\%) into infected tissue cages, as demonstrated by aspirating the infecting bacteria $60 \mathrm{~min}$ after injection of fresh serum into tissue cages and testing the staphylococci in a phagocytic assay against peritoneal exudate PMNLs. In five assays, killing of these reopsonized bacteria improved from $35.3 \% \pm 12.4 \%$ to $71.6 \% \pm 4.1 \%(P<0.01)$. Finally, the opsonic coating of $S$. aureus at $20 \mathrm{hr}$ was poor (figure 4, right) regardless of the size of the initial inoculum, which varied from $10^{3} \mathrm{cfu}$ to $10^{8} \mathrm{cfu}$. In 12 assays, killing of aspirated $S$. aureus could be improved from $38.2 \% \pm 5.3 \%$ to $88.8 \% \pm 2.0 \%(P<$ 0.001 ) by in vitro reopsonization with $10 \%$ pooled guinea pig serum. In summary, these experiments suggest that opsonic coating of $S$. aureus strain Wood 46 is incomplete at $20 \mathrm{hr}$ after infection and that this defect can be corrected by addition of fresh guinea pig serum either into the tissue cage or to the phagocytic assay.

\section{Discussion}

The factors promoting foreign body infection are not well understood. In this report we have described an experimental guinea pig model that 


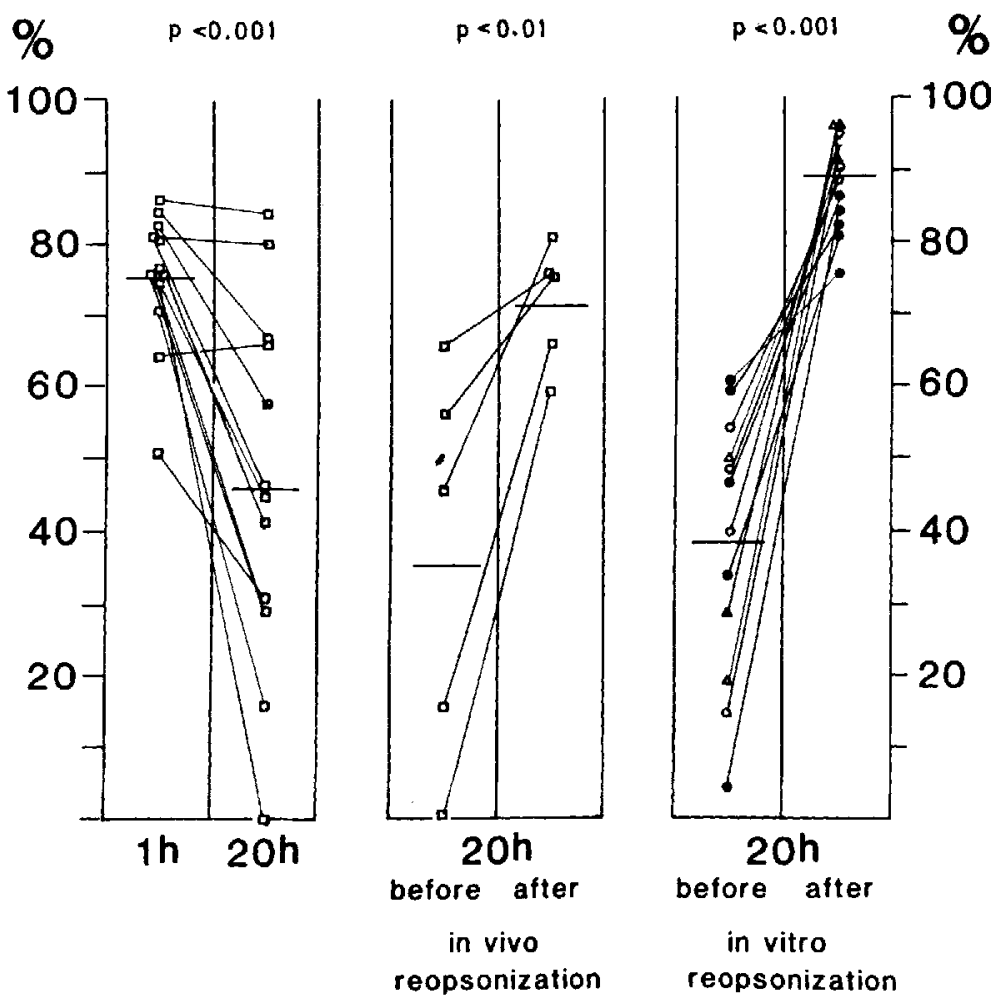

Figure 4. Opsonic activity bound to Staphylococcus aureus strain Wood 46 at intervals after experimental infection of tissue cages in guinea pigs: (left) 1 and $20 \mathrm{hr}$ after infection with $10^{7} \mathrm{cfu}$; (middle) $20 \mathrm{hr}$ after infection with $10^{7} \mathrm{cfu}$ before and after in vivo supplementation of tissue cage fluid with $0.5 \mathrm{ml}$ of fresh autologous serum (final concentra-

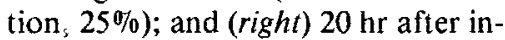
fection with (O) $10^{3} \mathrm{cfu}$, (๑) $10^{4} \mathrm{cfu}$, $(\Delta) 10^{6} \mathrm{cfu}$, and $(\Delta) 10^{8} \mathrm{cfu}$ before and after in vitro reopsonization with $10 \%$ pooled serum for a $30-\mathrm{min}$ period. Data are percentages of killing of $S$. aureus isolated from infected tissue cages after incubation for $\mathbf{3 0} \mathrm{min}$ in a phagocytic assay with $5 \times 10^{6}$ polymorphonuclear leukocytes from peritoneal exudate. permits exploration of these factors and reproduces the main characteristics observed in its clinical counterpart. After sc implantation of polymer tissue cages, injection of $10^{2} \mathrm{cfu}$ of an organism of low virulence such as $S$. aureus strain Wood 46 led uniformly to local infection in $<20$ hr. Infection did not spread to any other organ and healed after elimination of the foreign body. These observations, as well as the generally accepted concept that the main host defense mechanisms against local infections with $S$. aureus include opsonization and phagocytosis $[13,33]$, led us to focus our analysis of these host factors only over the first $20 \mathrm{hr}$ of infection. S. aureus strain Wood 46 was used in all experiments to avoid interference of staphylococcal protein A with IgG; this strain has been repeatedly shown to contain negligible amounts of protein $A[26,34]$ and to require complement only for optimal opsonization $[13,24,26]$. Although several biochemical determinations in tissue cage fluid differed from values in serum (data not shown), their variations were not sufficient to inhibit phagocytosis [35-39]. Such an effect, as well as a deleterious effect of tissue cage fluid on PMNLs, was further ruled out by appropriate mixing experiments involving preincubation of tissue cage fluid with competent blood PMNLs.

Our observations have identified two host defense defects in the neighborhood of the foreign body that are manifested at distinct stages in an infection-namely, poor PMNL activity at the beginning and a steadily decreasing efficiency of opsonization during the course of the disease.

Initially, opsonization of strain Wood 46 was adequate and could therefore not account for the high susceptibility to infection in our model. Moreover, in vitro preopsonization of the infecting strain did not prevent the development of infection after inoculation into tissue cages. Our data further suggest that at this early stage, the PMNLs residing in sterile tissue cage fluid were deficient in their phagocytic bactericidal function when compared with control PMNLs from either blood - the milieu from which they are originating - or peritoneal exudates obtained by a single soluble stimulus. This defect could be demonstrated under the standard conditions of a conven- 
tional phagocytic assay, as well as at a bacteria/ PMNL ratio of $1: 250$, which was the condition encountered in tissue cage fluid. Finally, this phagocytic bactericidal deficit in PMNLs from tissue cages tested two weeks after implantation was also evident when these cells were compared with PMNLs from an exudate of the same age, produced by soluble stimuli administered over 14 days.

Several aspects of this phagocytic bactericidal defect in PMNLs from tissue cages merit comment. (I) The development of a control system reproducing the conditions of a chronic exudate in the absence of a foreign body was of importance to compare the phagocytic function of PMNLs of similar ages in the presence and the absence of a foreign body. The identical time elapsed between the onset of these protracted stimuli (tissue cages or glycogen), the cytology of the two exudates, and the results of histopathologic examination of the two surrounding tissues suggest the presence of cell populations of the same age. This issue, however, can be resolved unambiguously only by future experiments involving comparison of pulselabeled PMNLs; for the time being, comparison of PMNLs from blood and exudate has been considered as an adequate procedure in similar experiments [40]. (2) The observed phagocytic bactericidal defect in PMNLs from tissue cages is all the more striking because Van Epps and Garcia have demonstrated that PMNLs from peritoneal exudates of guinea pigs elicited by a soluble stimulus actually show increased, rather than decreased, metabolic activity [40].

In keeping with our results obtained with PMNLs from tissue cages, Klock and Bainton [41] and Klock and Stossel [42] have demonstrated that intimate contact of PMNLs with glass or nylon wool will lead not only to activation of their oxidative metabolism and to degranulation, but also to a decrease in the cells' phagocytic bactericidal function. Electron microscopic data obtained with our model have confirmed that PMNLs in close contact with tissue cages show decreased granule contents.' Degranulation and metabolic alterations have been described for other systems in-

\footnotetext{
1 I. Joris, W. Zimmerli, G. Majno, and F. A. Waldvogel, "Foreign Body Reactions: Morphology of Inflammatory and Phagocytic Cells," manuscript in preparation.
}

volving PMNLs in contact with foreign, nonphagocytosable surfaces [43-45]. Taken together, these in vitro results suggest that intimate contact of PMNLs with foreign, nonphagocytosable surfaces might be detrimental to these cells, as suggested by the results of our experimental model. Finally, the deficit observed in PMNLs from tissue cages affected ingestion as well as bactericidal function, an observation suggesting that several subcellular mechanisms are altered. The mechanisms underlying these various alterations remain to be defined.

In contrast to these observations for the early stage of infection, opsonic coating of the infecting microorganism $S$. aureus strain Wood $46-$ presumably by functional C3 [46] - was markedly decreased during the course of the infection. This observation is open to at least two interpretations. Either decreased opsonization of S. aureus might be a consequence of the imbalance between the rate of coating of bacteria with functionally active $\mathrm{C} 3$ and the logarithmic growth of the organisms, or cleavage of the opsonically active factor by $\beta-1-\mathrm{H}$-globulin, $\mathrm{C} 3 \mathrm{~b}$ inactivator, and proteases [47-51] could have occurred during the development of a purulent infection. Loss of opsonic activity, as well as proteolytic cleavage of $\mathrm{C} 3$, has been recently demonstrated in several exudates rich in PMNLs [13, 15, 24]. Finally, our experiments showed that PMNLs attracted into the infected tissue cages displayed normal phagocytic bactericidal function, a finding which is apparently in contradiction with our observations in sterile tissue cages. In the case of a sterile tissue cage, however, the foreign body itself is probably responsible for the attraction of PMNLs; in the case of an abscess, additional chemoattractants such as bacterial polypeptides [52] are liberated, thus allowing PMNLs to accumulate in the fluid phase without being in contact with the foreign body. Intimate contact of PMNLs with foreign surfaces has indeed been shown to be necessary to alter the cells' metabolism and phagocytic functions [41, 42].

In conclusion, the phagocytic bactericidal defect in PMNLs from sterile tissue cage fluid probably represents one of the several determinants of foreign body infection and allows other pathogenic factors to progress during the first hours of the disease. Some of these factors 
may include organic substances coating the foreign body, which may protect bacteria from phagocytosis [53]; bacterial adhesion to foreign material [54]; and formation of a bacterial "glycocalyx" [55], which reduces bacterial accessibility to phagocytes and/or antibiotics. The animal model described here should permit the investigation of these and other possible factors that predispose foreign bodies to infection.

\section{References}

1. Bernhard, V. M. Management of infected vascular prostheses. Surg. Clin. North Am. 55:1411-1417, 1975.

2. Bhat, D. J., Tellis, V. A., Kohlberg, W. I., Driscoll, B., Veith, F. J. Management of sepsis involving expanded polytetrafluoroethylene grafts for hemodialysis access. Surgery 87:445-450, 1980.

3. Kloster, F. E. Complications of artificial heart valves. J.A.M.A. 241:2201-2203, 1979.

4. Charnley, J. Postoperative infection after total hip replacement with special reference to air contamination in the operating room. Clin. Orthop. 87:167-187, 1972.

5. Infected hip prostheses [editorial]. Br. Med. J. 280:1241$1242,1980$.

6. Ahlberg, А., Carlsson, $\AA$. S., Lindberg, L. Hematogenous infection in total joint replacement. Clin. Orthop. 137: 69-75, 1978.

7. Courtiss, E. H., Goldwyn, R. M., Anastasi, G. W. The fate of breast implants with infections around them. Plast. Reconstr. Surg. 63:812-816, 1979.

8. Georgiade, N. G., King, E. H., Harris, W. A., Tenery, J. H., Schlech, B. A. Effect of three proteinaceous foreign materials on infected and subinfected wound models. Surgery 77:569-576, 1975.

9. Hunter, G., Dandy, D. The natural history of the patient with an infected total hip replacement. J. Bone Joint Surg. [Br.] 59:293-297, 1977.

10. Elek, S. D., Conen, P. E. The virulence of Staphylococcus pyogenes for man: a study of the problems of wound infection. Br. J. Exp. Pathol. 38:573-586, 1957.

11. James, R. C., MacLeod, C. J. Induction of staphylococcal infections in mice with small inocula introduced on sutures. Br. J. Exp. Pathol 42:266-277, 1961.

12. Noble, W. C. The production of subcutaneous staphylococcal skin lesions in mice. Br. J. Exp. Pathol. 46:254-262, 1965.

13. Lew, P. D., Zubler R., Vaudaux, P., Farquet, J. J., Waidvogel, F. A., Lambert, P.-H. Decreased heat-labile opsonic activity and complement levels associated with evidence of $\mathrm{C} 3$ breakdown products in infected pleural effusions. J. Clin. Invest. 63:326-334, 1979.

14. Lew, D. P., Despont, J.-P., Perrin, L. H., Aguado, M.-T., Lambert, P. H., Waldvogel, F. A. Demonstration of a local exhaustion of complement components and of an enzymatic degradation of immunoglobulins in pleural empyema: a possible factor favouring the per- sistence of local bacterial infections. Clin. Exp. Immunol. 42:506-514, 1980.

15. Suter, S., Nydegger, U. E., Roux, L., Waldvogel, F. A. Cleavage of $\mathrm{C} 3$ by neutral proteases from granulocytes in plcural empyema. J. Infect. Dis. 144:499-508, 1981.

16. Stossel, T. P. Phagocytosis [parts 1-3]. N. Engl. J. Med. 290:717-723, 774-780, 833-839, 1974.

17. Sveen, K., Hofstad, T. Use of preformed cavities in rabbits for the quantitation of leukocyte chemotaxis caused by bacterial lipopolysaccharides. Acta Pathol. Microbiol. Scand. [B] 84:252-258, 1976.

18. Gerding, D. N., Moore, B. M., Russ, T. E., Peterson, L. R. Local cellular response to staphylococcal challenge in an abdominal abscess model. In J. D. Nelson and C. Grassi [ed.]. Current chemotherapy and infectious diseases. American Society for Microbiology, Washington, D.C., 1980, p. 841-842.

19. Bergan, T. Pharmacokinetics of tissue penetration of antibiotics. Rev. Infect. Dis. 3:45-66, 1981.

20. Gerding, D. N., Hall, W. H., Schierl, E. A., Manion, R. E. Cephalosporin and aminoglycoside concentrations in peritoneal capsular fluid in rabbits. Antimicrob. Agents Chemother. 10:902-911, 1976.

21. Stossel, T. P., Murad, F., Mason, R. J., Vaughan, M. Regulation of glycogen metabolism in polymorphonuclear leukocytes. J. Biol. Chem. 245:6228-6234, 1970.

22. Hisatsune, K., Kobayashi, K., Nozaki, S., Muramatsu, I. Phagocytosis-stimulating activity of tuftsin analogs. Microbiol. Immunol. 22:581-584, 1978.

23. Chenoweth, D. E., Lane, T. A., Rowe, J. G., Hugli, T, E. Quantitative comparisons of neutrophil chemotaxis in four animal species. Clin. Immunol. Immunopathol. 15: 525-535, 1980.

24. Zwahlen, A., Nydegger, U. E., Vaudaux, P., Lambert, P.-H., Waldvogel, F. A. Complement-mediated opsonic activity in normal and infected human cerebrospinal fluid: early response during bacterial meningitis. J. Infect. Dis. 145:635-646, 1982.

25. Vaudaux, P., Waldvogel, F. A. Gentamicin antibacterial activity in the presence of human polymorphonuclear leukocytes. Antimicrob. Agents Chemother. 16:743$749,1979$.

26. Spika, J. S., Verbrugh, H. A., Verhoef, J. Protein A effect on alternative pathway complement activation and opsonization of Staphylococcus aureus. Infect. Immun. 34:455-460, 1981.

27. Leijh, P. C. J., van Den Barselaar, M. T., van $Z$ wet, T. L., Dubbeldeman-Rempt, I., van Furth, R. Kinetics of phagocytosis of Staphylococcus aureus and Escherichia coli by human granulocytes. Immunology 37:453-465, 1979.

28. Tan, J. S., Watanakunakorn, C., Phair, J. P. A modified assay of neutrophil function: use of lysostaphin to differentiate defective phagocytosis from impaired intracellular killing. J. Lab. Clin. Med. 78:316-322, 1971.

29. Mandell, G. L. Interaction of intraleukocytic bacteria and antibiotics. J. Clin. Invest. 52:1673-1679, 1973.

30. Kabat, E. A., Mayer, M. M. Experimental immunochemistry. 2nd ed. Charles C Thomas, Springfield, Ill., 1961, p. 133-152. 
31. Mancini, G., Carbonara, A. O., Heremans, J. F. Immunochemical quantitation of antigens by single radial immunodiffusion. Immunochemistry 2:235-254, 1965.

32. Eickenberg, H.-U. What is interstitial fluid? Biochemical and physiological analysis of fluid obtained from tissue cages. Scand. J. Infect. Dis. [Suppl.] 14:166-170, 1978.

33. Verbrugh, H. A. The phagocytic response in host resistance against staphylococcal infections. Spirit Offset, Rotterdam, 1979, p. 150.

34. Sjöquist, J., Stålenheim, G. Protein A from Staphylococcus aureus. IX. Complement-fixing activity of protein A-IgG complexes. J. Immunol. 103:467-473, 1969.

35. Stossel, T. P., Alper, C. A., Rosen, F. S. Serum-dependent phagocytosis of paraffin oil emulsified with bacterial lipopolysaccharide. J. Exp. Med. 137:690-705, 1973.

36. Craddock, P. R., Yawata, Y., VanSanten, L., Gilberstadt, S., Silvis, S., Jacob, H. S. Acquired phagocyte dysfunction: a complication of the hypophosphatemia of parenteral hyperalimentation. N. Engl. J. Med. 290: 1403-1407, 1974.

37. Weston, W. L., Huff, J. C., Humbert, J. R., Hambidge, K. M., Neldner, K. H., Walravens, P. A. Zinc correction of defective chemotaxis in acrodermatitis enteropathica. Arch. Dermatol. 113:422-425, 1977.

38. Babior, B. M. Oxygen-dependent microbial killing by phagocytes [parts 1 and 2]. N. Engl. J. Med. 298:659668, 721-725, 1978.

39. Mandell, G. L. Bactericidal activity of aerobic and anaerobic polymorphonuclear neutrophils. Infect. Immun. 9:337-341, 1974.

40. Van Epps, D. E., Garcia, M. L. Enhancement of neutrophil function as a result of prior exposure to chemotactic factor. J. Clin. Invest. 66:167-175, 1980.

41. Klock, J. C., Bainton, D. F. Degranulation and abnormal bactericidal function of granulocytes procured by reversible adhesion to nylon wool. Blood 48:149-161, 1976.

42. Klock, J. C., Stossel, T. P. Detection, pathogenesis and prevention of damage to human granulocytes caused by interaction with nylon wool fiber: implications for filtration leukapheresis. J. Clin. Invest. 60:1183-1190, 1977.

43. Henson, P. M. Interaction of cells with immune complexes: adherence, release of constituents, and tissue injury. J. Exp. Med. 134(Suppl.):114S-135S, 1971.

44. Wright, D. G., Gallin, J. I. Secretory reponses of human neutrophils: exocytosis of specific (secondary) granules by human neutrophils during adherence in vitro and during esudation in vivo. J. Immunol. 123:285-294, 1979.

45. Yanai, M., Quie, P. G. Chemiluminescence by polymorphonuclear leukocytes adhering to surfaces. Infect. Immun. 32:1181-1186, 1981.

46. Stossel, T. P., Field, R. J., Gitlin, J. D., Alper, C. A., Rosen, F. S. The opsonic fragment of the third component of human complement (C3). J. Exp. Med. 141: 1329-1347, 1975.

47. Law, S. K., Fearon, D. T., Levine, R. P. Action of the C3b-inactivator on cell-bound C3b. J. Immunol. 122: 759-765, 1979.

48. Law, S. K., Lichtenberg, N. A., Levine, R. P. Evidence for an ester linkage between the labile binding site of $\mathrm{C} 3 \mathrm{~b}$ and receptive surfaces. $\mathrm{J}$. Immunol. 123:13881394, 1979.

49. Carlo, J. R., Ruddy, S., Studer, E. J., Conrad, D. H. Complement receptor binding of C3b-coated cells treated with $\mathrm{C} 3 \mathrm{~b}$ inactivator, $\beta-1-\mathrm{H}$ globulin and trypsin. J. Immunol. 123:523-528, 1979.

50. Fearon, D. T., Austen, K. F. Activation of the alternative complement pathway with rabbit erythrocytes by circumvention of the regulatory action of endogenous control proteins. J. Exp. Med. 146:22-33, 1977.

51. Pangburn, M. K., Schreiber, R. D., Müller-Eberhard, H. J. Human complement C3b inactivator: isolation, characterization, and demonstration of an absolute requirement for the serum protein $\beta-1-\mathrm{H}$ for cleavage of C3b and C4b in solution. J. Exp. Med. 146:257-270, 1977.

52. Russell, R. J., Wilkinson, P. C., McInroy, R. J., McKay, S., McCartney, A. C., Arbuthnott, J. P. Effects of staphylococcal products on locomotion and chemotaxis of human blood neutrophils and monocytes. J. Med. Microbiol. 9:433-449, 1976.

53. Peters, G., Locci, R., Pulverer, G. Microbial colonization of prosthetic devices. II. Scanning electron microscopy of naturally infected intravenous catheters. Zentralbl. Bakteriol. [B] 173:293-299, 1981.

54. Katz, S., Izhar, M., Mirelman, D. Bacterial adherence to surgical sutures: a possible factor in suture induced infection. Ann. Surg. 194:35-41, 1981.

55. Costerton, J. W., Geesey, G. G., Cheng, K.-J. How bacteria stick. Sci. Am. 238(1):86-96, 1978. 